\title{
Retailing under resale price maintenance: economies of scale and scope, and firm strategic response, in the inter-war British retail pharmacy sector
}

Article

Accepted Version

Scott, P. and Walker, J. T. (2018) Retailing under resale price maintenance: economies of scale and scope, and firm strategic response, in the inter-war British retail pharmacy sector. Business History, 60 (6). pp. 807-832. ISSN 1743-7938 doi: https://doi.org/10.1080/00076791.2017.1340455 Available at https://centaur.reading.ac.uk/71114/

It is advisable to refer to the publisher's version if you intend to cite from the work. See Guidance on citing.

To link to this article DOI: http://dx.doi.org/10.1080/00076791.2017.1340455

Publisher: Taylor \& Francis

All outputs in CentAUR are protected by Intellectual Property Rights law, including copyright law. Copyright and IPR is retained by the creators or other copyright holders. Terms and conditions for use of this material are defined in the End User Agreement. 


\section{CentAUR}

Central Archive at the University of Reading

Reading's research outputs online 


\title{
Retailing under Resale Price Maintenance. Economies of scale and scope, and firm strategic response, in the inter-war British retail pharmacy sector
}

\author{
Peter Scott and James T. Walker \\ Henley Business School at the University of Reading
}

\section{Notes on contributors}

PETER SCOTT is professor of international business history at the Henley Business School, University of Reading. He has published extensively on retailing, consumer durables production and marketing, housing, and household expenditure. His monograph, The Making of the Modern British Home: The Suburban Semi and Family Life between the Wars, was published by Oxford University Press in 2013.

JAMES T. WALKER is head of international business and strategy at Henley Business School, University of Reading. His research agenda is characterized by the application of empirical methods to solve real world problems and issues past and present. He has published in journals as diverse as Research Policy and Journal of Economic History, examining spatial competition in product markets and between firms, particularly in the retail and automobile industries; varieties of capitalism; academic performance and pay; and attitudes to multinational enterprises.

\section{Acknowledgments}

We thank the staff of the Boots plc Archives; The University of York's Borthwick Institute; the Royal Pharmaceutical Library; and Shop Direct (holders of the Woolworths archives at the time of our research) for their generous help. We also thank Tom Buckley, Andrew 
Hull, and the participants of seminars at the ABH/GUG Conference, Berlin, the EBHA conference, Bergen, and three anonymous referees, for their comments. Any errors are our own.

Abstract: We examine the impact of Resale Price Maintenance (RPM) on market structure, productivity, and competitive advantage in British retail pharmacy. In contrast to influential studies, but consistent with contemporary and recent work, we show that the major multiples were able to ameliorate the negative growth impacts of RPM. Higher profit margins - principally from larger manufacturer discounts and backward integration - were used to fund initiatives aimed at boosting aggregate sales and economies of scale and scope. These relationships are explored using a recently-discovered national establishment-level survey of retail pharmacists' costs and margins, together with internal data for Boots Ltd.

Key words: Economies of Scale, Economies of Scope, Resale Price Maintenance, Retail Productivity, Own Brands

\section{Introduction}

Some influential studies have argued that prior to the Second World War the growth of chain stores and other large-scale retail formats in Britain did not produce substantial productivity benefits and may even have acted to constrain retail productivity growth. Alfred Chandler argued in Scale and Scope that - owing to severe market segmentation in Britain between working and middle-class customers - large-scale retailers focused on selling a narrow range of goods to a mainly working-class customer base. They thus reaped economies of scale, through higher stock-turn, but failed to achieve economies of scope ${ }^{\mathrm{i}}$ 
A later study by Stephen Broadberry is more pessimistic, finding that British labour, and total factor, productivity in distribution actually declined over the inter-war period. Broadberry partly attributes this to a deterioration in the competitive environment, owing to growing retail market concentration and the rise of resale price maintenance (RPM) for branded goods. ${ }^{\text {ii }}$

These findings are sharply at odds with contemporary and near-contemporary analyses of British retailing, which generally emphasise the productivity advantages of large-scale formats. For example J.B. Jefferys' seminal 1954 study highlighted the impact of inter-war multiple retailers in generating economies of scale and scope and reducing segmentation between working and middle-class markets. ${ }^{\text {iii }}$ Moreover, claims that the "professional" retail sector faced declining productivity are based on highly problematic data. Broadberry's negative inter-war British retail labour productivity estimate was derived from aggregate data showing distribution employment growth outpacing output growth. ${ }^{\text {iv }}$ However, this includes a growing "long tail" of subsistence retailers, who set up "front room" and other very small shops as a response to mass unemployment. Retail consultant O.W. Roskill estimated that in 1939, despite the reduction in unemployment from its peak levels of the early 1930s, there were still around 375,000 - 400,000 such shops, which probably outnumbered "professional" independent shopkeepers. ${ }^{\mathrm{v}}$ This is corroborated by a number of government-sponsored and other enquiries. ${ }^{\mathrm{vi}}$

Recent research on British interwar department and variety stores has found strong economies of scale and scope and substantial productivity growth. ${ }^{\text {vii }}$ However, these sectors required a minimum scale of operation significantly above that of typical small retail establishments and thus do not provide a comparison for the whole of the retail firm, 
or store, size distribution. Moreover, these sectors were relatively weakly impacted by RPM, which grew sharply over the inter-war era to encompass around 30 percent of consumer expenditure on goods. ${ }^{\text {viii }}$ RPM has been proposed as an important factor fossilising the market structure of retailing in the sectors it most strongly impacted on, by preventing multiples from expanding their market share through price competition. ${ }^{\mathrm{ix}}$

This study examines the inter-war evolution of a sector strongly impacted by RPM, retail pharmacy. Pharmacy was an important sector of retailing. Chemists and drug stores were estimated to account for $80-85$ per cent of sales for proprietary and non-proprietary medicines (excluding dispensing); over 75 per cent of invalid and infant foods; and 59-65 per cent of beauty preparations, perfumes, toiletries, and toothpaste and tooth brushes; while chemists and opticians accounted for $55-65$ per cent of photographic goods. ${ }^{\mathrm{x}} \mathrm{RPM}$ was particularly strong for most major classes of chemists' goods. For example, Jefferys estimated that around 50-60 per cent of proprietary medicine sales in 1938 were subject to collective RPM, while a further substantial proportion were subject to RPM by their manufacturers. ${ }^{\text {xi }}$

A major newly-discovered 1939 national census of retail pharmacists (excluding public companies), together with internal data from the market leader, Boots, enable us to examine how productivity varied for pharmacists across almost all the firm, and store-size, distribution. We first examine the evolution of the sector, the ways in which RPM influenced its growth and structure, and the strategies developed by major multiples to mitigate the impact of RPM on their sales and market share growth. We find that for Boots and (on the basis of limited available evidence) the other national chain, Timothy White and Taylors, profits were boosted by higher manufacturer discounts and backward 
integration into manufacturing. These major cost advantages were translated into retail sales growth via strategies of store expansion (both green field and acquisition), together with boosting customer flow by product range diversification and intensive promotional activity. Such activities enabled the national multiples (but not the independents) to avoid the scenario - predicted by the theory of imperfect competition - that the initial rise in pharmacists' profits generated by RPM would stimulate market entry by new competitors, who would bid away the abnormal profits while further fragmenting the local and national market. ${ }^{\text {xii }}$

\section{Historical development}

The early development of retail pharmacy was characterised by efforts to gain professional privileges that would provide legislative barriers to competition from other retailers. The Pharmaceutical Society of Great Britain [hereafter Pharmaceutical Society], founded in 1841, secured legislation (the Pharmacy Acts of 1852 and 1868) to limit the use of titles such as "chemist" and "druggist" to people qualified under the Society's examinations and prevent other retailers from selling goods scheduled as "Poisons" under the latter Act. ${ }^{\text {xiii }}$ They also sought to prohibit retail pharmacists constituted as limited liability companies ("company chemists"), headed by non-qualified persons. However, a test case brought by the Society ended in an 1880 House of Lords appeal decision that companies were not constrained by these Acts, so long as the sale of poisons was undertaken by a qualified person. ${ }^{\text {xiv }}$ Consequently, over the following 15 years more than two hundred retail pharmacy companies were established. ${ }^{\mathrm{xv}}$

The second half of the nineteenth century witnessed rapid vertical specialisation between manufacturing, wholesaling and retailing, largely driven by the growth of 
intensively advertised patent and proprietary (manufacturer-branded) medicines. ${ }^{\text {xvi }}$ Proprietaries, which rapidly became the most important class of chemist's goods, did not require the employment of a qualified chemist and reduced the importance of the chemist's skills in making up medicines from ingredients. They thus markedly increased the scope for market entry by other retailers, such as grocers. This, together with a trend towards further diversification into new product lines such as photographic goods and opticians' services, acted to further increase the importance of commercial, rather than pharmacy, skills for success in the chemists' trade. ${ }^{\text {xvii }}$

Independent chemists perceived a further major threat to their livelihoods - the new multiple pharmacy chains. Jefferys estimated that in 1890 there were only four pharmacy multiples with over 10 branches each: Boots, Timothy White, Taylor's Drug Co., and W.T. Warhurst. ${ }^{\text {xiii }}$ However, the following decades witnessed rapid expansion, as shown in Table 1. Pre-1914 multiple pharmacy was mainly composed of local chains, together with a hand full of regional firms and one national name, Boots Ltd. Born in Nottingham in 1850, Jesse Boot worked full-time in his family's herbal medicine shop from the age of 13. He later moved into proprietary medicines, using a highly successful business formula of buying in bulk, undercutting local competitors and vigorously advertising low prices to boost stock-turn. ${ }^{\text {xix }}$ He later established own brands to substitute for more expensive nationally advertised ones and employed advertising that directly attacked what he described as the high prices of the established pharmacy trade. ${ }^{\mathrm{xx}}$

\section{[Table 1 near here]}

By the Edwardian era Boots were also beginning to emphasise services, even hosting art exhibitions at some of their largest stores. ${ }^{x x i}$ This transition owed much to 
Florence Annie Rowe, who Jesse Boot married in 1886. Florence, who came from a retailing family, was responsible for the development of Boots' "No. 2 department" selling stationery, books, pictures, silverware and other "fancy goods", and for introducing lending libraries and cafes into the larger stores. ${ }^{\text {xii }}$ This assisted Boots in developing large, departmentalised, stores, which were advertised as appealing to both "the classes and masses". xxiii This was part of a conscious attempt to broaden Boots' market segment beyond its original mainly working-class customer base. ${ }^{\text {xiv }}$ Rapid development of new stores, including the acquisition of various smaller chemist chains, increased Boots' branch network to 180 shops by 1900 and 560 in 1914, while Boots' manufacturing activities were also substantially expanded. ${ }^{x x v}$

The major regional chains generally followed similar strategies to Boots. For example, Taylor's of Leeds originally pursued a policy of cutting patent medicine prices to the bone and, where possible, pushing their own products - with staff incentivised via commission. ${ }^{\text {xxvi }}$ Taylor's, together with some other large chains such as Parke's Drug Stores, later also followed Boots' strategy of developing large, imposing, flagship stores, with a broad range of merchandise, including "fancy goods". Best practice rapidly diffused between the large chains, partly owing to widespread "poaching" of staff. xxvii

The independent pharmacy sector responded to the competitive threat from largescale retailers via lobbying for RPM, to remove their price advantage, and (unsuccessfully) for legislation to prohibit or restrict company chemists. In 1896 a small-scale London pharmacist, William Glyn-Jones, established the Proprietary Articles Trade Association [P.A.T.A.] one of the earliest successful collective attempts to enforce RPM. P.A.T.A. aimed to ensure an adequate profit rate for retailers and wholesalers of proprietary 
medicines (while securing their goodwill for the manufacturers and thus avoiding excessive substitution of branded medicines by cheaper products). ${ }^{\text {xxviii }}$ P.A.T.A. was governed by a council of (originally) 30 members: comprising equal numbers of representatives of retailers, wholesalers, and manufacturers. These established lists of prices for proprietary goods (set so as to offer a certain gross margin when purchased in ordinary quantities), published in their Anti-Cutting Record, circulated to all chemists and other traders holding patent medicine licenses. ${ }^{x x i x}$

Retail trade associations were generally developed and dominated by the sector's largest firms. ${ }^{\mathrm{xxx}}$ Conversely, P.A.T.A.'s structure reflected its origins as a "grass roots" movement, initially championed by independent traders rather than the sector's major players. Pharmacists were relatively well-organized compared to other retailers, reflecting the control of entry to the profession by the Pharmaceutical Society's apprenticeship system and statutory qualifying exams. Moreover, P.A.T.A was built on a pre-existing substructure of local chemists and druggists associations, with its conferences largely comprising delegates from these associations. The multiples were slower to fall into line; indeed Boots refused to join (though they eventually tacitly accepted P.A.T.A.'s prices). ${ }^{\mathrm{xx} i}$ The scope of goods covered by P.A.T.A.'s lists grew rapidly, from 142 articles in 1897 to over 2,000 by the beginning of 1924. ${ }^{\text {xxxii }}$ P.A.T.A. also broadened its scope to cover other categories of goods typically sold through pharmacists, especially toiletries.

The inter-war era witnessed both a major extension in the volume of chemists' merchandise subject to collective or individual RPM and higher price-maintained gross margins. The main hike in margins occurred in 1920, when P.A.T.A. used increased railway charges as grounds for raising retailers' margins to at least 25 per cent (compared 
to around 20 per cent prior to the First World War) and wholesalers' margins to 12.5 per cent. By 1939 P.A.T.A. aimed to secure retailer discounts of at least 25 per cent on proprietary medicines, surgical preparations, and disinfectants; 20-25 per cent on proprietary infant and invalid foods; and 33.3 per cent on proprietary perfumes, cosmetics, soaps, and other toiletries. ${ }^{\text {xxxii }}$

Yet the spread of RPM did not halt the growth of market concentration. Multiple retailers increased their share of retail pharmacy sales from 10.0-12.0 per cent in 1910 to 18.0-22.0 in 1925 and 33.0-37.0 in 1939 (compared to the multiples' estimated share of total retail trade of $18.0-19.5$ per cent). ${ }^{x x i v}$ There was also a marked increase in concentration; by the late 1930s two firms - Boots, and Timothy White and Taylors collectively controlled some 90 per cent of branches for multiple pharmacy stores with 25 or more branches. ${ }^{\mathrm{xxxv}}$ In March 1939 Boots had 1,195 branches, with 14,055 branch staff, while the Timothy Whites \& Taylors group had some 768 branches. ${ }^{\text {xxvi }}$ The sector was thus transformed into a duopoly of national chains, together with a large number of singlebranch enterprises and small multiples (plus department stores and co-operatives, with 1939 market shares of 2.5-4.0 and 3.0-4.5 per cent respectively). ${ }^{x x v i i}$ Rising market concentration was also evident in other heavily price-maintained sectors selling fastmoving goods, such as groceries. ${ }^{\text {xxxviii }}$ We now examine the ways in which the major multiples were able to substantially expand market share, despite being unable to engage in price competition for most of their manufacturer-branded goods.

\section{Strategies for expanding market share under RPM}


Retailers typically analyse their performance using the Gross Margin (the price mark-up, minus shrinkage and subsequent mark-downs), the Total Expenses ratio, and the Net Margin (Gross Margin minus Total Expenses), all expressed as a proportion of net retail sales. It is generally assumed that firms aim to maximise the growth of aggregate profits (possibly subject to the constraint of some minimum acceptable Net Margin), which in turn approximates to turnover multiplied by Net Margin. For any given Net Margin and level of total merchandise stocks, turnover is determined by stock-turn (the number of times their stores turn over stock each year). ${ }^{\mathrm{xxxix}}$

Scale economies in purchasing, from volume discounts and cutting out the wholesaler, act to increase Gross Margin for large-scale retailers (assuming they charge the same prices as their smaller competitors). However, mass retailers generally find it profitable to cut prices in order to boost stock-turn and market share, to an extent which typically more than counter-acts the positive impact on Gross Margin of purchasing economies, leaving them with a lower Gross Margin than smaller competitors. Meanwhile, their Total Expenses ratios are reduced via firm- and store-level economies of scale and scope, better inventory control, and the greater customer flow generated by lower prices, prime retail pitches and strong retail branding, which may enable them to achieve higher Net Margins, despite substantially smaller Gross Margins.

Assuming that effective RPM applies to all their merchandise, large-scale retailers would be compelled to sell at competitors' prices, but would still enjoy significant discounts for bulk purchase. Moreover, their high and relatively stable Gross Margins would incentivise them to integrate backwards into manufacturing - as the returns from 
investment in own-brand goods would be higher, while the risk associated with that investment (from price wars and similar downward pressure on margins) would be lower. Carlo Morelli has argued that this reduction in risk was a particularly important motivation for grocery chain investment in own brands over 1954-64. ${ }^{\mathrm{xl}}$ Major pharmacy chains had strong advantages over their smaller rivals regarding own brands, as drug R\&D, manufacture, and advertising are subject to economies of scale and scope. Furthermore, consumer acceptance of pharmacy private labels was particularly reliant on promotional expenditure and strong retail branding, to persuade customers that these were at least equally safe and effective as intensively-advertised proprietary brands.

Thus, in contrast to competitive price-setting, multiples could be expected to have markedly higher, rather than lower, Gross Margins than smaller competitors. They would still enjoy efficiency savings in Total Expenses, thus producing a much larger net margin. However, their growth of total profits and market share might be expected to be lower, as customers would have no price incentive to choose them over less efficient competitors (for manufacturer-branded goods), and stock-turn would thus be substantially reduced. Moreover, RPM prices were typically set at levels sufficiently high to keep small retailers in business (given that manufacturers considered RPM valuable partly as a means of maximising their number of points of sale). ${ }^{x l i}$

There were, however, a number of strategies whereby large pharmacy chains could translate their higher profit rates - from manufacturer discounts, own brands and scale economies - into aggregate sales and market share growth. These can be classified into two broad categories: increasing customer flow at their existing points of sale, by incentivising customers to visit their stores (despite the convenience advantages of more local 
competitors, selling manufacturer-branded goods at identical prices); and strategies aimed at expanding their number of points of sale.

These have been explored in the post-1945 RPM literature. Burt and Sparks set out a 'spiral of growth' model, whereby larger retailers use their higher Net Margin (from greater purchase discounts and high margin own brand sales) to develop in-store services and facilities. These reduce Net Margin, but increase stock-turn by attracting additional customers. If successful, this would have a similar effect to price reductions in raising sales growth and sales per square foot, thus lowering unit costs (both in-store and across the organisation as a whole) and improving asset utilization, providing additional funds for continued improvements in services and facilities to further boost growth. ${ }^{\text {xli }}$

This literature identifies the ability of large retailers to secure preferential terms from manufacturers, and to develop strong home brands, as important drivers of industry concentration, both through 'organic' growth' (the development of new branches) and the acquisition of smaller competitors. ${ }^{\text {xliii }}$ RPM also makes expansion further down the retail hierarchy more attractive (especially for firms with saturated coverage of urban shopping centers), by offering attractive Gross Margins (further boosted by purchase discounts and home branding), to offset the lower store-level scale economies of shops serving smaller catchment areas. ${ }^{x l i v}$

\section{Market growth strategies for Boots and Timothy White and Taylors}

Boots' product selection, stock control, and inventory management systems received significant up-grading following its acquisition by U.S.-based United Drug Co. in 1920 (when an elderly and infirm Jesse Boot felt unable to continue running the business). 
United Drug Co. introduced American-style managerial systems, including profit-sharing remuneration for senior executives, advanced systems of statistically-based expense and stock control (which also provided performance benchmarks for individual stores) and geographic division of stores into territories, supervised by territorial general managers. ${ }^{x l v}$ However, following the initial reorganization American control proved fairly arms-length, with most senior managers being drawn from Boots staff. In 1932 a struggling United Drug Co. (now part of the larger Drug Incorporated) sold Boots back into British control, under a consortium headed by Jesse Boot's son John (who had remained a senior executive during the period of American control). ${ }^{x}{ }^{1 v i}$ Boots experienced significant growth over the interwar years. Total sales (including a small amount of wholesale business) rose from $£ 8,308,963$ in the year to $31^{\text {st }}$ March 1923 , to $£ 12,913,485$ in the year to $31^{\text {st }}$ March 1938 , while store numbers increased from 665 to 1,180 .

By 1929 there was effectively only one other large pharmacy multiple, the cluster of firms controlled by the financier Philip Hill, which were later formally merged into Timothy Whites and Taylors Ltd. Taylors Drug Co. Ltd - then operating 162 branches and a large factory -was purchased by a group controlled by Hill in 1927. Later that year Hill acquired Needhams Ltd (127 branches). Then in June 1928 Hill obtained control over Timothy White, operating 100 stores, which then acquired Hopes, Ltd, a chain of 32 hardware shops. Later in 1928 Hill made further acquisitions: Messrs. Parkes of London (42 stores) and Mortons Cash Chemists Ltd (22 stores) which, together with subsequent acquisitions in and around London, were incorporated as Taylors Cash Chemists (London), Ltd. ${ }^{\text {xlvii }}$ Hill was chairmen of these companies, which undertook considerable co-operation before their formal amalgamation in 1935. ${ }^{\text {xlviii }}$ The group had factories and warehouses in 
London, Leeds, and Portsmouth. Store management was divided territorially, with Territorial Group Managers controlling approximately 200 branches each, and a lower tier of Group Managers each supervising 35 branches. ${ }^{\text {xlix }}$

Timothy White and Taylors had some 764 stores by the beginning of $1938 .^{1}$ Those inherited from Timothy White were mainly 'dual' shops, selling chemists goods and hardware, with separate windows devoted to each; the group included 155 of these, plus 34 purely hardware stores. ${ }^{\text {i }}$ There are no available figures for group turnover, though the firm claimed to have served almost 66 million customers during the year to $31^{\text {st }}$ January 1938, which (assuming identical sales per customer) suggests that their sales amounted to around 39 per cent of the business conducted by Boots. However, their substantial hardware interests would have reduced their relative share of trade in chemists' goods. lii

Boots and (on the basis of the much more limited available evidence for this group) Timothy White and Taylors, reaped major profit advantages through higher purchase discounts and backward integration. Some manufacturers offered the same sliding scale of discounts for bulk purchases to both wholesalers and retailers; given that wholesaler margins were around 12.5-15 per cent in 1938, this provided major purchase cost advantages. ${ }^{\text {liii }}$ However, own brand merchandise offered even more attractive margins. The national multiples had much stronger manufacturing capabilities than the independents, as changes in pharmaceutical technology, involving complex organic chemicals and biological products unsuitable for small-scale manufacture, imposed a significant minimum efficient scale of output for many new medicines. ${ }^{\text {liv }}$ Meanwhile national sales made it practicable to produce a much broader range of medicines in-house, while strong retail brands increased public acceptance of own label goods. 
Own brands offered not only higher margins but control over retail prices and "exclusivity" - which was a significant advantage for some prestigious own brands, supported by extensive press advertising, such as Boots No. 7 beauty preparation range. Boots' significantly increased its proportion of own brand goods, capitalising on heavy investments in R\&D. In 1915 Boots established a Fine Chemical Department to meet war needs and substitute for products hitherto imported from Europe. Following the postArmistice downturn in the fine chemical market Boots' Research Department was reduced to three or four chemists. However, investment in pharmaceutical research continued. For example, shortly after the isolation of insulin in 1921 a Boots' chemist, Joseph Marshall, was sent to obtain process details for its extraction and in 1923 Boots' Research Department began work on insulin and arsphenamine. Over the next four years the department substantially increased its range of pharmacological and bacteriological activities. This was further boosted in 1927 by the appointment of a new research director, Dr F.H. Pyman, who brought five postgraduate chemists with him from Manchester, facilitating a further expansion of activities. ${ }^{\text {Iv }}$

The value of Boots' manufacturing supplies to retail increased by 76.2 per cent between the years ending $31^{\text {st }}$ March 1925-1938, substantially out-pacing their 40.7 per cent growth in retail sales. ${ }^{\text {lvi }}$ The ratio of manufacturing supplies to retail (before adding wholesale and retail margins) to total store turnover (at retail prices) rose steadily from 15.8 per cent in the year to $31^{\text {st }}$ March 1925 to 17.8 per cent in the year to $31^{\text {st }}$ March 1932 . It then leapt to over 21 per cent for the next four years, while falling back to an average of just over 19 per cent during 1937-39. However, a better comparison is provided in the notes 
to Boots' internal accounts, which provide data (from the year ended $31^{\text {st }}$ March 1936 onwards) at retail prices.

In the year to $31^{\text {st }}$ March 1939 Boots' pharmaceutical manufacturing activities generated retail sales of $£ 3,937,572$, representing 47.5 per cent of sales in merchandise classes that included proprietary medicines ("packed goods", drugs, and dispensing). Moreover, while Boots achieved a Gross Margin of 36.1 percent on proprietary articles, its Gross Margin on own goods in these classes amounted to 62.1 percent. However, these incurred extra costs of advertising and sales commission; an analysis for the previous year indicated that if these were factored in the Gross Margin on own goods would fall from 62.77 per cent to something in excess of 52.7 per cent. ${ }^{\text {lvii }}$ Timothy White and Taylors also developed a wide range of own brands, including medicines under Gee's, Magors, and other brand names; toilet requisites under the Shahls brand, and Gordon brand hardware lines and cleaning agents. lviii $^{\text {in }}$

Maximising sales for own brand products entailed generating confidence in both the company's retail brand and in their specific own brands, especially for pharmaceuticals, which were "credence" goods, with a history of quackery and dubious practice encompassing both retail own brands and well-known proprietary names, such as Beechams. ${ }^{\text {lix }}$ Boots invested in extensive "goodwill" advertising to promote their reputation for high quality medical supplies and advice. Adverts focused on the quality of their analytical laboratories, in contrast to the more dubious methods of some drug producers, with slogans such as "YESTERDAY ... a tiny herbalist's Today ... A GREAT LABORATORY where you are protected from unsafe drugs ..." or "Manufactured by Boots... a guarantee of safety and accuracy." ${ }^{, 1 x}$ 
In 1922 Boots appointed P.C. Brett as their first medical advisor. Brett (who became a director in 1926) made valuable contacts with St. Thomas's Hospital, which fed into research projects. He also contributed to the development of the firm's own brands. Boots employed testimonials from doctors (and built up goodwill with medical staff by offering them discounts), and publicized the advice services their stores offered with adverts such as "ASK NURSE! You'll find her in the Surgical Department of the larger Boots shops ready to help you with your more personal purchases." "Ixi Given that, like doctors, pharmacists provided diagnostic services to consumers who might be unsure of either their ailment and/or the best medication for it, the ability of Boots to position itself as a highly trusted and respected source of medicines and advice (which, by the 1920s, was justified by its investment in modern $\mathrm{R} \& \mathrm{D}$ and production facilities) provided it with a major reputational advantage over smaller competitors. ${ }^{1 x i}$

Boots further enhanced their corporate image by investing heavily in the development and promotion of prestigious new product brands carrying the firm's name. . $^{\text {Iiii }}$ One outstanding example was Boots "No. 7" series of deluxe beauty preparations. The perfumer Pierre Bongard was recruited from Paris to produce new fragrances; packaging was designed by the prestigious Carlton Studios, and the leading beauty writer Mrs Darlymple was engaged to help with publicity. Boots invested substantially in the product launch, training "Number 7 girls" who toured their stores, arranging stock and giving special demonstrations (in the stores, leading local hotels, and the Ideal Home Exhibition). Beauty parlors were also launched in the larger stores to promote the range - which both became one of Boots' most successful and enduring brands and helped raise the firm's 
overall reputation in the beauty products field. ${ }^{\text {lxiv }}$ No.7 also provided Boots with exclusivity for what became a prestigious product brand.

The wider range of goods available in the national multiples' larger stores, their open display, and freedom to browse, were also important service attractions. ${ }^{1 \times v}$ For example, during the 1920s Boots continued its tradition of developing some large departmentalised stores, including five "Wonder Shops" - combining state of the art shop design and amenities such as fitted kitchens, first aid stations, ballrooms and ladies' retiring rooms while also being designed to tastefully blend into the local streetscape. ${ }^{1 x v i}$

Both the national multiples substantially diversified their product ranges, thus drawing in more customers and boosting utilisation rates for their sales floorspace. Boots developed two particularly distinctive offerings: lending libraries and cafes. In March 1939 there were some 460 libraries, and 19 cafes, among Boots' 1,195 branches. ${ }^{\text {xvii }}$ An internal analysis found that their libraries were only generally profitable in larger stores, which could attract over 1,500 subscribers. However, their presence in many stores where they were not directly profitable (which comprised 319 or the 423 branches operating for two years or more in 1938) reflected both firm-level scale economies in bulk purchasing of books and the fact that they boosted the stores' other sales. ${ }^{\text {lxviii }}$

A similar rationale underpinned their provision of cafes at a few very large stores, reflecting a strategy also pursued by some other major high street chains, such as Woolworths and Marks \& Spencer (who, like Boots, found that cafes were not justified solely in terms of direct profitability). ${ }^{\text {xix }}$ However, the decreasing average size of new Boots stores placed a constraint on the proportion that could offer these extra lines and services. ${ }^{\text {lxx }}$ Reaping economies of scope may also have underpinned the development of 
dual chemists and hardware stores by Timothy Whites - a strategy extended to the group as a whole following their merger with Taylors.

Own brands, cafes, libraries, and new, non-pharmacy, product lines were also important as means to differentiate retail brands, given that differentiation by price was generally not permitted. ${ }^{1 \times x i}$ The Boots Library could also be seen as an early form of "loyalty-related initiative", providing benefits that necessarily entailed return visits. ${ }^{\text {Ixxii }}$

Boots and Timothy White and Taylors were also active in expanding their points of sale, through both acquisitions and "green field" store development. A strategy of corporate acquisition was vigorously pursued by what became the Timothy White and Taylors's group, under the guiding influence of Philip Hill (who also, unsuccessfully, made a bid for Boots in 1932). This was assisted by the fact that that, apart from Boots, the other major chains of the early 1920s were regionally-based firms, with little territorial overlap with each other. Boots' inter-war expansion strategy also placed increased emphasis on buying going concerns, though these were typically single store or other relatively small businesses. This was more expensive than buying vacant premises, but allowed Boots to obtain local goodwill, diffused tensions with independent pharmacists - a particularly vocal and well-organised group - and had the advantage of reducing inter-firm competition. ${ }^{\text {lxxiii }}$

Both companies also expanded via diffusion down the retail hierarchy, through opening new branches. At the end of 1923 Boots had 665 stores, with average sales per store of $£ 12,495$; by $31^{\text {st }}$ March 1938 they had 1,180 stores and average sales per store of $£ 10,413{ }^{\text {lxxiv }}$ Timothy White and Taylors also supplemented their strategy of corporate acquisitions with a complementary policy of new store development. For example, from 27th September 1936 to 1st January 1938 they opened 19 new 'dual'- (chemist and 
hardware) shops and one single function chemist shop. ${ }^{\text {lxx }}$ The aim of both companies was to develop stores of optimal size for their local catchment areas and each thus also engaged in significant programmes of store extension and modernization in locations where market conditions justified this. ${ }^{1 \times x v i}$

\section{The independent chemist under RPM}

The number of small-scale chemists (with 10 or fewer branches) rose from 9-10,000 in 1914 to $12-13,000$ in $1938{ }^{1 x x v i i}$ Rapid growth continued into the 1930 s, with the Pharmaceutical Society census identifying an 18 per cent increase in the number of chemists' stores between 1930 and 1937..$^{\text {lxviii }}$ The pharmacist's apprenticeship system requiring trainees to serve under a qualified pharmacist while undergoing academic training, culminating in qualifying exams - acted to proliferate the number of retail outlets. Pharmacists found it financially attractive to take on apprentices, but could not generally offer them jobs after qualification; the typical outcome being that they set up a (often undercapitalised) pharmacy store on their own account.

Meanwhile independent chemists faced a progressive erosion in the value of their technical skills, owing to the continued expansion of proprietary medicines relative to cures made up by the pharmacist from raw ingredients. Medical practitioners were said to increasingly prescribe proprietaries rather than write out prescriptions for generic medicines, even when these could be easily compounded in-store. ${ }^{1 \times x i x}$ Furthermore, intensive advertising increased the tendency for customers to demand a specific brand, rather than explaining their symptoms to the chemist. Pharmacists' margins were protected by RPM, yet the absence of any requirement for a trained pharmacist when selling 
proprietary medicines resulted in other retailers being drawn to these goods by their attractive margins. ${ }^{1 \times x x}$ Conversely, the Pharmaceutical Society report noted that intensive advertising for branded and proprietary goods had contributed to substantial aggregate growth in medicine sales. ${ }^{1 \times x x i}$

The independents had one major advantage - convenience - which was more important for chemist goods that for merchandise involving infrequent major purchases (such as clothing) or multiple item purchases (such as groceries). Many independents sought to increase turnover by diversifying into related goods, such as toiletries, perfumes, cosmetics, and beauty products. However, given that these also typically had high, pricemaintained, gross margins, they again faced growing competition from non-pharmacy stores. ${ }^{1 \times x x i i}$ Photographic goods was another growing area of business and here pharmacists proved more successful in holding their traditional dominant position, assisted by manufacturers who sought to limit the number of sales points. ${ }^{\text {lxxiii }}$ Yet the broadening product mix and greater emphasis on commercial skills and assets - including merchandise display, shop design, and well-located stores - raised overhead charges, requiring more rapid stock-turn to maintain net profits. ${ }^{\text {lxxiv }}$

Despite protection from the full force of market competition through RPM and, for some lines, by the requirement for professional qualifications, Roskill noted a trend for pharmacists' salaries to decline towards levels prevailing in other branches of retailing - as predicted by the theory of imperfect competition, as applied to RPM, discussed earlier. ${ }^{1 \times x x v}$ The Pharmaceutical Society also concluded that independent pharmacists faced declining profit rates (though a survey question regarding the trend of profits over 1930-37 produced 
inconclusive results) and - despite their growing absolute sales - a declining proportion of the total pharmacy trade. .xxxvi $^{\text {par }}$

The Pharmaceutical Society suggested developing 'voluntary chain' type arrangements, whereby pharmacists would co-operate in areas such as purchasing stock, uniform pricing, using standard shop fronts and equipment to create a corporate brand, and joint provision of advertising and other services. However, they were deeply skeptical regarding whether the individualistic nature of most independent pharmacists would allow

such co-operation. ${ }^{\text {lxxxvii }}$ Most independents preferred to focus on renewed attempts to exclude non-pharmacy competitors. The most important initiative was the Chemists Friends Scheme, launched by the National Pharmacists Union in 1935. ${ }^{\text {xxxviii }}$ Manufacturers were asked to limit retail distribution of their proprietaries to pharmacists, compliant firms being placed on the "Chemists' Friends" list. Participating retailers were in turn requested to give special prominence to their products. ${ }^{1 \times x x i x}$ However, the Pharmaceutical Society enquiry found that most items covered in the scheme had, in practice, previously only been sold by pharmacists, while the scheme had not materially increased the proportion of goods restricted to pharmacists (with the exception of some new products, where manufacturers needed their support to create a market). ${ }^{\mathrm{xc}}$

\section{New data sources for retail pharmacists' costs, margins, and productivity}

The absence of any British retail census before 1950 restricts performance analysis of retail establishments (other than department stores and Co-operatives) to those few major multiples that have surviving internal management accounting records. However, retail pharmacy is unique in that there was a national "census" covering all classes of independent and multiple pharmacists other than the two national chains. We use this census in 
conjunction with firm and store-level internal managerial accounting records from Boots Ltd, held in the Boots plc archives, to provide a performance analysis over the entire pharmacy size distribution (with the exception of Timothy White and Taylors, which has no suitable surviving data). To the best of our knowledge the data sources for this analysis have never been previously used in academic or other published work.

The census was conducted as part of the Pharmaceutical Society's enquiry into the problems of the retail trade and how these could be addressed. ${ }^{x c i}$ Following an experimental census of 50 shops, all retail pharmacy stores were sent census forms in November 1938 (receipt of returns being closed in February 1939), relating to their last full accounting years (mainly the year to $31^{\text {st }}$ March 1938). ${ }^{\text {xcii }}$ Only Boots and Timothy White and Taylor were excluded (presumably because it would be impossible to anonymise their data, given their much larger size, and that - as public companies - they would be unwilling to reveal such data).

Approximately 12,500 census forms were sent out, of which 1,682 were returned, making this by far the largest pre-1950 British retail establishment survey. After rejecting forms that omitted essential data or appeared to have faulty arithmetic or implausible data, there were 1,254 usable responses. ${ }^{\text {xiii }}$ The enquiry's committee believed that the replies were representative of pharmaceutical businesses as a whole. Unfortunately only the processed census, rather than the individual returns, have survived.

In many cases the proprietor did not provide a figure for their salary and the average salary for the relevant turnover range was then used. ${ }^{\text {xiv }}$ Salaries were strongly dependent on turnover; only stores with sales of $£ 2,000-2,500$ or more paid average salaries over $£ 250$ (equivalent to what was then considered the minimum threshold adult "middle-class" 
income). Some 54.9 per cent of stores in the census were below this size threshold, suggesting that the average retail pharmacist was positioned towards the bottom of the white-collar income spectrum. ${ }^{\mathrm{xcv}}$ Some 221 shops included in the census were branches of "multiples" of 2-30 stores, though just over half of these had only two shops. The census found that the multiples achieved substantially higher turnover per store, and gross and net margins, than single store firms. ${ }^{\mathrm{xcvi}}$

Data for Boots are derived from a number of accounting records. These include the "Statistical Record", a series of annual report for the directors, providing extensive data on Boots' firm-level performance and sales for years ending $31^{\text {st }}$ March, with comparisons for earlier years; a series of detailed internal firm-level accounts, and notes to these accounts (again for years ending $31^{\text {st }}$ March); and cards recording the performance of particular stores from 1923 onwards, with data for years ending $31^{\text {st }}$ December. ${ }^{\text {xcvii }}$

Table 2 shows the bi-modal firm size distribution of the British pharmaceutical sector. There were 9,257 single store firms and some 1,354 very small multiples of 2-10 stores (including 895 unincorporated retailers with an average of 2.41 shops and 459 companies with an average of 2.99). There was only one larger unincorporated firm (with 17 stores) and 20 companies with $11-50$ stores (averaging 22.05 stores). ${ }^{\text {xcviii }}$ Then at the other end of the size distribution, though excluded from the Census, was Boots, with 1,195 branches by March 1939, and Timothy Whites \& Taylors, with 768 branches. ${ }^{\text {xcix }}$ This hollowing out of firms in the middle size range may reflect the fact that small stores had the key advantage of convenience, while the national chains were in the strongest position to capitalise on economies of scale and scope. 
Table 3 provides an analysis of retail pharmacists' sales by class of goods. Unfortunately the Census only provided rankings, rather than percentages of sales. We have added similar data for Boots, from their "Statistical Record" (again expressed as rankings, to make them consistent with the rest of the table). The table shows that comparison of large and smaller retailers is not substantially distorted by differences in product mix. In all cases proprietary medicines are the largest sales category, followed by either other medicines or toiletries and sundries, with photographic goods occupying fourth or fifth place. There is some tendency for the importance of National Health Insurance dispensing to fall as store size increases, while the main difference between Boots and the survey stores is Boots' higher ranking for "other" items (reflecting its significant activity in fancy goods, stationery and art, and library and café facilities). However, this category accounted for only 14.7 per cent of Boots sales (reflecting the fact that they were mainly restricted to the larger stores).

Table 4 examines the variation in margins and expenses for retail pharmacists by turnover, again with aggregate data for Boots added. The survey shows relatively little variation in gross margin by size of store, with a standard deviation across the size range of only 1.13 percentage points, as would be expected given the prevalence of RPM. However, expenses ratios show strong scale economies, falling from 37.9 per cent for stores with annual turnover of $£ 500-1,000$ to 26.2 per cent for stores with net sales of over $£ 4,000$. This appears to be strongly linked to faster stock-turn. Unfortunately, the survey does not disaggregate stocks from stocks and fittings, which prevents direct calculation of stock-turn rates. However, the ratio of stocks and fittings to turnover shows a very sharp decline, from 47.3 per cent for the smallest class of store to 30.2 per cent for stores with a 
turnover of $£ 4,000-5,000$ and 32.5 per cent for those with sales of over $£ 5,000$. Consequently net profit rates are strongly related to size, ranging from a slight loss for stores with under $£ 1,000$ turnover to 9.0 per cent for those with annual sales over $£ 5,000$.

Table 4 also provides aggregate data for Boots, for the year to the end of March 1938. Boots' Gross Margin is shown to be significantly lower than that for any turnover band in the Pharmaceutical Society survey, reflecting the fact that the firm fixed gross margins on own brand goods at a relatively low level (30.5 per cent). Moreover, at least some of their discounts for manufacturer brand bulk purchases were internally allocated to their wholesale/warehousing division rather than to their retail division.

Comparisons of Total Expenses and Net Margins are distorted, as Boots' retail section took on some of the promotional costs of their own-brand goods, by paying commission to retail staff on their sales (as was noted by the firm's accountants). If commission and bonus payments, which comprised 10.6 per cent of branch wages and salaries, are removed (to make the retail data comparable with stores selling externallysourced goods, for which promotional activity was undertaken by the manufacturer), the Total Expenses ratio would be reduced to 25.5 per cent and the retail Net Margin increased from 4.5 to 6.0 per cent. $^{\mathrm{c}}$ However, this assumes that all Boots' commission and bonus payments are made for own-goods sales and that, in their absence, fixed salaries and wages would be no higher.

So the real comparative figure for Boots' retail expenses lies somewhere between 24.4 and 25.5 per cent, probably towards the lower end of this range. Following the same logic, their Net Margin would be nearer 6.0 than 4.5 per cent. However, this ignores the profits from Boots' manufacturing and wholesale functions; which would further increase 
net profit, to 8.6 per cent of turnover. Yet even this figure is lower than that for the largest independent stores in the sample, with sales of over $£ 5,000$, which had a 9.0 per cent average Net Margin. Given Boots' substantially greater average store size than even the largest turnover class in the census, this suggests that the positive relationship between store size and Net Margin shown in the census may not be evident for higher store turnover levels. The following section investigates this.

\section{The relationship between store size and performance at Boots}

Performance records have survived for a number of individual Boots stores, enabling examination of stores in common ownership - and, therefore, controlling for firm-level scale economies in areas such as purchasing, manufacturing, and central administration. These cover calendar years (rather than Boots' accounting year, which was to the end of March) and incorporate wholesale, as well as retail, expenses. Table 5 shows key performance variables for the year to $31^{\text {st }}$ December 1937 (the closest date to the Pharmaceutical Society census), arranging the stores into four quartiles, by turnover. Stores that opened or closed during the year were excluded (as their turnover figures would not cover the full year) and a small number of others had to be omitted owing to missing or dubious data (for example, where Gross Margin figures did not match the sum of operating

expenses and net margin). This left a useable sample of 87 stores (with the highest quartile shown in the table having one fewer store than the others).

\section{[Table 5 near here]}

The sample had substantially larger average sales per store $(£ 15,571$, compared to $£ 10,840$ for Boots' retail section annual turnover per store to $31^{\text {st }}$ March 1938). However, 
the range of store sizes matches that of the company, the smallest store in the sample having sales of $£ 1,965$ (almost identical to the average for Boots’ 20 smallest stores), and the largest having a turnover of $£ 113,129$ (considerably higher than the average for their 20 largest stores) enabling us to draw inferences for the chain as a whole. ${ }^{\text {ci }}$

As Table 5 shows, aggregate turnover for the sample was dominated by the top quartile, with average sales some six times as high as stores in the third quartile. This was true, to a lesser extent, for the company, with their 20 largest stores in March 1938 accounting for 12.48 per cent of annual turnover for all 1,180 branches. These thus clearly played an important role in increasing Boots aggregate sales and generating company-level scale economies. ${ }^{\text {cii }}$

Pay-roll expenses ratios declined significantly for larger stores. This data can also be used to estimate sales per employee, using the ratio of Boots' retail section wages and salaries during the year to $31^{\text {st }}$ March 1938, divided by the number of branch employees. ${ }^{\text {ciii }}$ The figures show that sales per employee rose substantially with turnover, especially over quartiles 1-3. Larger stores are also shown to have reaped economies of scope, with sales per customer in the highest quartile being substantially above the others. However, the largest quartile incurred greater rental, and other non-labour, costs, collectively giving it a significantly higher Total Expenses ratio than Quartile 3. This in turn results in a significantly lower Net Margin for quartile 4 relative to quartile 3. Given the limited sample size (87 stores) in this analysis, a similar exercise was conducted for the year to $31^{\text {st }}$ December 1938, with a useable sample of 88 stores that had a large overlap with, but was not identical to, the Table 5 sample. This corroborates the above findings, with the larger 
stores enjoying higher sales per member of staff, and per customer, but incurring higher Total Expenses, and lower Net Margins, than Quartile 3.

The lower profit margins for Boots' largest stores, relative to those in Quartile 3 (which spanned Boots' average sales per store), are consistent with the hypothesis that RPM diverted some trade from central to local points of sale. Large, central, stores incur high rental costs and typically have a broader product mix than smaller stores in the same chain (including many goods that have a lower stock-turn than the chain's core lines, other things being equal). Such higher costs are typically offset by greater customer numbers, that boost overall stock-turn. However, under RPM customers might find it more convenient to make frequent small purchases from their local chemist, rather than waiting to make larger weekly purchases from a high-street store. This problem was recognized by Boots. A long-term trend of falling sales for some central stores in large cities - such as Liverpool, Manchester, Sheffield, Newcastle, and Birmingham - was partly attributed to the opening of smaller Boots' branches that encroached on their traditional catchment areas. $^{\text {civ }}$

The Boots store-level data provide a (unbalanced) sample of 151 stores over 19231938, allowing us to look at the evolution of store size over time and the extent to which this is consistent with the growing influence of RPM. The sample composition is broadly representative of the population of Boots stores, with 41 stores entering from 1924 onwards (38.8 per cent more than were present at the beginning of the period), slightly lower than that for the full store population (43.6 per cent).

Specifically, we would expect to find a shift in the stores' size distribution. Figure 1 illustrates the distribution of stores over time between four size categories [small, with 
sales of less than $£ 5,000$ per annum (denoted 1); small-medium with sales between $£ 5,001$ and $£ 10,000$ per annum (2); medium-large with sales of $£ 10,001$ and $£ 20,000$ (3); and large stores with sales over $£ 20,000]$. The proportion of small stores grows from one quarter of the sample in 1923 to $55 \%$ 1931, stabilizing around 50\% thereafter. The relative proportion of large stores remains quite stable, while the rise in the importance of small stores is mainly counter-balanced by falls in the proportions for the small-medium and mediumlarge categories.

\section{[Figure 1 near here]}

The spread of RPM can be expected to progressively reduce the minimum threshold store size that Boots would consider, given that it acts to both reduce the optimal size of store and - at least in the short-term - increase the relative profitability of smaller stores. Figure 2 illustrates the shift in the relationship been size (in terms of sales) and net margin for three benchmark years. We find a non-linear relationship between the two variables, with the tangential point capturing the store size that has the highest profit margin. Figure 2 also highlights that there was a reduction in maximum net margins from 18 per cent in 1924 to about 8 per cent for the 1938 tangential point. This is consistent with the standard theory of imperfect competition, discussed earlier, which predicts that the abnormal profits generated by RPM will be progressively reduced across the sector by firm entry.

\section{[Figure 2 near here]}

In order to examine how these correspond to specific size categories we correlate the two variables at our four size groupings over the 1920s and 1930s. The correlations are highest for the 1920s for the smallest stores (those with less than $£ 5,000$ in sales) with net margins being high and positive at the $1 \%$ level of significance $(0.503, p>0.01)$, while the 
next size category has a much smaller and statistically insignificant relationship between these variables. At the other end of the spectrum the larger stores (with sales between £10$20,000$ and over $£ 20,000)$ have large negative correlations $(0.283, p>0.01$ and 0.304 , $\mathrm{p}>0.01$, respectively). The relationship between sales and net margins shifts in the 1930s, as shown in Table 6. Small stores' net margins are still positively related, but the correlation coefficient has more than halved for the smallest group compared to the 1920s. Indeed, the optimum size of store now appears to be in the $£ 5,000$ - 10,000 turnover range (though negative returns are only slight over the $£ 10,000-£ 20,000$ range and relatively low compared to the 1920s even for the largest stores). This is consistent with the hypothesis that Boots' expansion of own brand sales reduced the cost penalty of operating large stores, relative to smaller ones, over the inter-war period.

\section{[Table 6 near here]}

Our data also enable us to estimate the extent that Boots expanded their store network via store development or purchasing competitors. Direct information on whether stores were purchased or developed is unavailable, however we can infer this by examining the growth in store sales. We find a clear differentiation between stores with growth rates of more than 15 per cent in the year after they were established, presumably signifying new entrants, and those with growth rates below 15 per cent, which we assume to be acquired existing pharmacies. As discussed above, purchasing established firms was more expensive than buying vacant premises, but allowed Boots to obtain local goodwill, diffused tensions with independent pharmacists, and reduced inter-firm competition. The data reveal that the proportion of new entrants under this definition is about three quarters of the 41 stores, 
indicating that new store development was the primary strategy. This may have partly reflected expansion into new shopping areas, such as new-built suburban shopping parades.

\section{Conclusions}

The experience of independent pharmacists and very small chains under RPM conforms to the predictions of neoclassical imperfect competition theory. Despite gross margins that were high relative to most other sectors of retailing, ${ }^{\mathrm{cv}}$ and rising national consumer expenditure on chemists' goods, small retailers nevertheless faced declining incomes owing to the rapid growth of local competition, both from pharmacists and other retailers.

Conversely, for the major national multiples the predictions of standard imperfect competition theory, as applied to RPM, do not hold. These enjoyed substantial firm-level scale and scope economies, from manufacturers' discounts and backward integration into manufacturing. Increased profits generated by these advantages were translated into higher sales through strategies of intensive promotion (partly to strengthen corporate brands); store-based services; a more diverse merchandise assortment to draw in customers; and territorial expansion - through both pharmacy store acquisitions and 'greenfield' developments.

The national retailers did face productivity penalties for their larger central stores, with declining returns to store size evident for branches with revenues much in excess of $£ 10,000$. This contrasts starkly with evidence on store-level scale economies in this period for sectors much less constrained by RPM. For example, recent studies of variety stores, drapers, and department stores indicate that substantial scale economies are evident even 
at very high turnover levels (well beyond the turnover of the largest Boots' branches). ${ }^{\mathrm{cvi}}$ This reflects the negative impacts of RPM on customer flow for large, centrally-located stores, while high rental costs for central shopping pitches were determined in competition with retailers who were less constrained by RPM. Nevertheless, these large stores made a major contribution to total firm turnover and thus underpinned Boots' strong firm-level scale and scope economies. ${ }^{\text {cvii }}$

RPM thus created a bi-modal industry structure, with an 'independent' sector (mainly comprising single store firms and very small multiples) witnessing substantial growth in store numbers, but declining market share, together with what became a duopoly of national chains that enjoyed both rising store numbers and substantial market share growth. Moreover, these national firms utilized their strong firm-level scale economies to expand further down the retail hierarchy, "cherry-picking" the most attractive local shopping pitches through both acquisitions and green-field investments. This process looked set, in the absence of government intervention, to eventually relegate the independents to a "fringe" of shopping pitches deemed uneconomic by the national multiples owing to their very small catchment areas.

RPM neither blocked the growth of large-scale retailing or the firm-level productivity advantages arising therefrom - though it did inhibit the store-level scale and scope economies evident in less price-controlled areas of multiple and department store retailing. Meanwhile there is little evidence that inter-war British retail pharmacists faced greater institutional barriers to competition, from RPM or other sources, than their overseas counterparts. Several European countries, including France and Germany, had wellestablished systems of state intervention to control drug prices and quality; limitations on 
the number of pharmacists per head of local population; and/or more general legislative restrictions on the growth of large-scale retailers. ${ }^{\text {cviii }}$ Even in the USA RPM for fast-moving goods had its widest application in the drug trade, having achieved almost complete coverage by the late 1930s. Moreover, U.S. drug retailers' trade associations were more successful in pressing for restrictive legislation to reduce competition from the multiples than their UK counterparts. ${ }^{\text {cix }}$ So while the scope of competition in British retail pharmacy was "constrained" relative to some other areas of retailing, these constraints were typically weaker than those facing pharmacists in most Western nations.

\section{References}

Akehurst, Gary, "Concentration in retail distribution: measurement and significance," 2745 in Gary Akehurst and Nicholas Alexander (eds), Retail Structure. London: Frank Cass, 1995.

Ailawadi, K. and Keller, K.L. "Understanding Retail Branding, Conceptual Insights and Research Priorities.” Journal of Retailing, 80, no. 4 (2004): 331-42.

Ailawadi, K., Pauwels, K. and Steenkamp, J.B.E.M. "Private-label Use and Store Loyalty." Journal of Marketing, 72, 6 (2008): 19-30.

Bookbinder, P. Simon Marks, Retail Revolutionary. London: Weidenfeld \& Nicolson, 1993.

Broadberry, S. Market Services and the Productivity Race, 1850-2000. Cambridge: CUP, 2006. 
Brownfield-Pope, A.M., "From Chemist Shop to Community Pharmacy: An Industry Wide Study of Retail Chemists and Druggists, c1880-1960." Unpublished Ph.D diss., University of East Anglia, 2003.

Burt, Steve L., and Sparks, Leigh, "Power and Competition in the UK Grocery Market," British Journal of Management, 14 (2003), 237-254.

Chandler, A.D. Scale and Scope. The Dynamics of Industrial Capitalism. Cambridge, MA: Belknap, 1990.

Chapman, S. Jesse Boot of Boots the Chemists. London: Hodder \& Stoughton, 1974.

Chapman, S. "Boot, Jesse, first Baron Trent (1850-1931).” Oxford Dictionary of National Biography, Oxford University Press, 2004

[http://www.oxforddnb.com/view/article/31965, accessed 10 March 2010].

Corley, T.A.B. Beechams, 1848-2000. From Pills to Pharmaceuticals. Lancaster: Curible, 2011.

Curtis, C.A. "Resale Price Maintenance.” Canadian Journal of Economics and Political Science, 4, no. 3 (1938): 350-61.

Darby, M.R. and Karni, E. "Free Competition and the Optimal Amount of Fraud." Journal of Law \& Economics. 16, no. 1 (1973): 67-88.

Geddes, K. and G. Bussey. Setmakers. A History of the Radio and Television Industry. London: Brema, 1991.

Godley, A.C. and Casson, M.C., ““'Doctor, Doctor...' Entrepreneurial Diagnosis and Market Making." Journal of Institutional Economics, 11, no. 3 (2015): 601-621.

Grant, Robert M. "Manufacturer-retailer Relations: the Shifting Balance of Power," 43-58 in Gerry Johnson (ed), Business Strategy and Retailing. Chichester: John Wiley, 1987. 
Greenwood, J.E. A Cap for Boots: An Autobiography. London: Hutchinson: Benham, 1977. Holloway, S.F. Royal Pharmaceutical Society of Great Britain 1841-1991. A Political and Social History. London: Pharmaceutical Press, 1991.

Jefferys, J.B. The Distribution of Consumer Goods: a Factual Study of Methods and Costs in the United Kingdom in 1938. Cambridge: CUP, 1950.

Jefferys, J.B. Retail Trading in Britain 1850-1950. Cambridge: CUP, 1954.

Kipping, S.A.B., "The Research Department of Boots Pure Drug Co. Ltd, Chemistry and Industry (1963), 302-10.

Koschate-Fischer, N., Cramer, J. and Hoyer, W.D. "Moderating Effects of the Relationship between Private Label Share and Store Loyalty." Journal of Marketing 78, no. 2 (2014): 69-82.

Levy, Herman, Retail Trade Associations. A New Form of Monopolist Organisation in Britain. London: Kegan Paul, 1942.

Mc Nair, M.P. "Chain Store Expenses and Profits: an Interim Report for 1932.” Harvard Bureau of Business Research Bulletin No. 94 (1934).

Mercer, H. "Retailer-supplier Relationships before and after the Resale Prices Act, 1964: a Turning Point in British Economic History?” Enterprise \& Society, 15, no.1 (2014): 132165.

Mills, D. "Why Retailers Sell Private Labels." Journal of Economics \& Management Strategy 4, no. 3 (1995): 509-528.

Morelli, Carlo, "Constructing a Balance between Price and Non-price Competition in British Multiple Food Retailing 1954-64,” Business History, 40 (1998), 45-61. 
Morelli, Carlo, "Information Costs and Information Asymmetry in British Food

Retailing,” The Service Industries Journal, 19 (1999), 175-86.

Phillips, S. "Chemists to the Nation": House Magazines, Locality and Health at Boots The Chemists 1919-1939." Management \& Organizational History, 3, no. 3-4 (2008): 239-55. Phillips, S. and Alexander, A. “An Efficient Pursuit? Independent Shopkeeping in 1930s Britain.” Enterprise \& Society 6, no. 2 (2005): 278-304.

Rowntree, Poverty and Progress. A Second Social Survey of York., London: Longmans, 1941.

Scott, P.M. and Walker, J.T., "Barriers to Industrialisation for Interwar British Retailing? The Case of Marks \& Spencer Ltd.” Business History, 59 (2017): 179-201.

Scott, P.M. and Walker, J.T., "The British 'Failure' that Never Was? The Anglo-American 'Productivity Gap' in Large-scale Interwar Retailing-Evidence from the Department Store sector.” Economic History Review, 65, no. 1 (2012): 277-303.

Scott, P.M. and Walker, J.T., "Large-scale Retailing, Mass-market Strategies and the Blurring of Class Demarcations in Interwar Britain," 99-126 in Paolo Di Martino, Andrew Popp, and Peter Scott (eds), People, Places, and Business Cultures. Essays in Honour of Francesca Carnevali. Woodbridge: Boydell, 2017.

Shaw, G., Alexander, A., Benson, J., and Jones, J. "Structural Trends in British Retailing: the Importance of Firm-level Studies”, Business History, 40, no. 4 (1998), 79-93.

Slinn, J. “The Boots Company plc.” In St James Press, International Directory of Company Histories. London: St. James Press (1992): 17-20.

Sneader, Walter E., "The Growth of Multiple Pharmacy in Great Britain,” essay submitted in fulfilment of the degree of B.Sc. in Pharmacy, Glasgow University, 1961. 
"Taylors (Cash Chemists) London Limited." Times [London, England] 12 Nov. 1928: 26. The Times Digital Archive. Web. Accessed 24 Feb. 2017.

UK, Board of Trade, Report of the Committee on Resale Price Maintenance (Cmd. 7696 of 1948-49).

Williams, B. The Best Butter in the World. A History of Sainsbury's. London: Ebury Press, 1994.

Wilson, J.F., Webster, A., and Vorberg-Rugh, R., Building Co-operation. A Business History of the Co-operative Group, 1863-2013. Oxford: Oxford U.P., 2013.

Winstanley, Michael, "Concentration and Competition in the Retail Sector, c. 18001990”, 236-262 in Maurice W. Kirby and Mary B. Rose (eds), Business Enterprise in Modern Britain. London: Routledge, 1994.

Yamey, B.S. "The Origins of Resale Price Maintenance. A Study of Three Branches of the Trade," Economic Journal, 62, no. 247 (1952): 522-45. 
Table 1: Estimates of the number of firms in the chemists' and druggist' trade with 10 or more branches, 1895-1939

\begin{tabular}{|c|c|c|c|c|c|c|c|c|c|c|}
\hline Branches & $10-24$ & & $25-49$ & & $50-99$ & & $100 \mathrm{o}$ & more & Total & \\
\hline Year & Firms & Branches & Firms & Branches & Firms & Branches & Firms & Branches & Firms & branches \\
\hline 1895 & 4 & 54 & 2 & 74 & 1 & 50 & 0 & - & 7 & 178 \\
\hline 1905 & 9 & 115 & 1 & 36 & 1 & 78 & 1 & 314 & 12 & 543 \\
\hline 1915 & 7 & 96 & 1 & 38 & 3 & 228 & 1 & 579 & 12 & 941 \\
\hline 1920 & 10 & 149 & 1 & 36 & 3 & 241 & 1 & 618 & 15 & 1,044 \\
\hline 1925 & 13 & 189 & 2 & 67 & 0 & 0 & 4 & 1,137 & 19 & 1,393 \\
\hline 1930 & 16 & 204 & 3 & 98 & 0 & 0 & 3 & 1,439 & 22 & 1,741 \\
\hline 1935 & 20 & 269 & 3 & 85 & 2 & 110 & 2 & 1,816 & 27 & 2,280 \\
\hline 1939 & 22 & 316 & 5 & 155 & 1 & 58 & 2 & 1,933 & 30 & 2,462 \\
\hline
\end{tabular}

Source: Jefferys, Retail Trading, p. 386. 
Table 2: The structure of the British retail chemist sector in 1938

\begin{tabular}{|l|r|r|r|r|}
\hline Branches & \multicolumn{2}{|c|}{ Firms } & \multicolumn{2}{c|}{ Stores } \\
\hline per firm & No. & \multicolumn{1}{c|}{$\%$} & No. & $\%$ \\
\hline 1 & 9,257 & 87.05 & 9,257 & 61.21 \\
\hline $2-10$ & 1,354 & 12.73 & 3,529 & 23.33 \\
\hline $11-50$ & 21 & 0.20 & 458 & 3.03 \\
\hline $51-500$ & 0 & 0.00 & 0 & 0.00 \\
\hline Over 500 & 2 & 0.02 & 1,880 & 12.43 \\
\hline Total & 10,634 & 100.00 & 15,124 & 100.00 \\
\hline
\end{tabular}

Source: Royal Pharmaceutical Library Archives, IRA 1996.432, Pharmaceutical Society of Great Britain, 'Report of the Committee of Enquiry, Part I' (May 1939). 
Table 3: sales by category of merchandise, classified by order of magnitude ( 1 being the largest category) for 446 shops examined in the Pharmaceutical Society survey, together with data for Boots Ltd

\begin{tabular}{|c|c|c|c|c|c|c|c|c|c|}
\hline Turnover $(£)$ & $500-1000$ & $1000-1500$ & $1500-2000$ & $2000-2500$ & $2500-3000$ & $3000-4000$ & $4000-5000$ & Over 5000 & Boots Ltd \\
\hline \multicolumn{10}{|l|}{ Medicines } \\
\hline Proprietary & 1 & 1 & 1 & 1 & 1 & 1 & 1 & 1 & 1 \\
\hline Non-proprietary & 2 & 2 & 2 & 3 & 3 & $2 *$ & $3 * *$ & 2 & 2 \\
\hline $\begin{array}{l}\text { Toiletries \& chemists' } \\
\text { sundries }\end{array}$ & 3 & 3 & 3 & 2 & 2 & $3^{*}$ & $2 * *$ & 3 & 3 \\
\hline Photographic & 5 & 5 & 5 & $5^{*}$ & 4 & 4 & $4 * * *$ & 4 & 5 \\
\hline \multicolumn{10}{|l|}{ Dispensing } \\
\hline NHI & 4 & 4 & 4 & $4^{*}$ & 5 & 5 & $5 * * *$ & 6 & 6 \\
\hline Private & 6 & 6 & 6 & 6 & 6 & 6 & $7 *$ & 5 & 7 \\
\hline Optical goods & 8 & 8 & 8 & 8 & $8^{*}$ & 8 & 8 & 8 & n.a. \\
\hline Other goods & 7 & 7 & 7 & 7 & $7 *$ & 7 & $6^{*}$ & 7 & 4 \\
\hline Shops in sample & 37 & 134 & 94 & 67 & 37 & 51 & 15 & 11 & 1180 \\
\hline
\end{tabular}

Sources: Boots Ltd, Boots plc Archives, Boots Statistical Record for year to $31^{\text {st }}$ March 1938; other retailers, Royal Pharmaceutical Library Archives, IRA 1996.432, Pharmaceutical Society of Great Britain, 'Report of the Committee of Enquiry, Part I (May 1939).'

Notes: Figures for the survey were presented only as rankings. Figures marked with the same number of asterisks (in each column) are approximately the same order of magnitude. Boots had no optician's department at this time (or classified sales in this category) and any optical sales in other departments can reasonably be assumed to be smaller than those in its classified categories. 
Table 4: Margins and expenses ratios for stores in the Census, and for Boots Ltd, for the year to $31^{\text {st }}$ March 1938

\begin{tabular}{|c|c|c|c|c|c|c|}
\hline Turnover & $\begin{array}{l}\text { Average } \\
\text { Turnover }\end{array}$ & $\begin{array}{l}\text { Gross } \\
\text { Margin }\end{array}$ & Expenses & $\begin{array}{l}\text { Net } \\
\text { Margin }\end{array}$ & $\begin{array}{c}\text { Stocks } \\
\& \text { fittings }\end{array}$ & Stores \\
\hline$£$ & $£$ & \multicolumn{4}{|c|}{ Per cent of turnover } & No. \\
\hline $500-1000$ & 829 & 37.4 & 37.9 & -0.5 & 47.3 & 93 \\
\hline $1000-1500$ & 1,273 & 36.0 & 32.4 & 3.6 & 40.5 & 330 \\
\hline $1500-2000$ & 1,743 & 35.1 & 29.8 & 5.3 & 37.3 & 266 \\
\hline $2000-2500$ & 2,239 & 34.6 & 28.2 & 6.3 & 32.7 & 185 \\
\hline $2500-3000$ & 2,710 & 35.1 & 26.9 & 8.1 & 33.1 & 116 \\
\hline $3000-4000$ & 3,380 & 34.0 & 25.6 & 8.4 & 34.2 & 147 \\
\hline $4000-5000$ & 4,377 & 33.9 & 26.2 & 7.7 & 30.3 & 57 \\
\hline Over 5000 & 7,056 & 35.2 & 26.2 & 9.0 & 32.5 & 60 \\
\hline Total (RPS Census) & 2,280 & 34.9 & 28.0 & 6.9 & 35.0 & 1,254 \\
\hline Boots (retail stores) & 10,413 & 31.5 & 27.0 & 4.5 & n.a. & 1,180 \\
\hline
\end{tabular}

Source: Pharmaceutical Society survey, as for Table 2, Boots Ltd, Boots plc Archives, Box 1167, detailed accounts and notes to the accounts for the year to $31^{\text {st }}$ March 1938.

Notes: Boots (all activities) includes wholesale sales to other retailers. 
Table 5: A quartile analysis of sales, margins and expenses for a sample of 88 Boots stores over the year to $31^{\text {st }}$ December 1937.

\begin{tabular}{|l|c|c|r|r|r|r|r|r|r|}
\hline & \multicolumn{2}{|l|}{ Turnover per: } & \multicolumn{5}{|l|}{ Margins: } & \multicolumn{2}{l|}{ Expenses: } \\
& Store & Customer (d) & Worker* & Gross & Net & Pay-roll & Rent & Other & Total \\
\hline Q1 & 2,530 & 11.81 & 661 & 42.2 & 2.7 & 19.7 & 5.8 & 14.0 & 39.5 \\
\hline Q2 & 4,092 & 14.34 & 864 & 39.9 & 6.5 & 15.0 & 5.7 & 12.7 & 33.5 \\
\hline Q3 & 8,174 & 15.83 & 982 & 39.0 & 8.7 & 13.2 & 5.9 & 11.1 & 30.3 \\
\hline Q4 & 49,009 & 22.34 & 1,010 & 40.2 & 6.3 & 12.9 & 6.5 & 14.5 & 33.9 \\
\hline Full & & & & & & & & & \\
sample & 15,571 & 19.76 & 974 & 40.1 & 6.5 & 13.3 & 6.3 & 13.9 & 33.6 \\
\hline
\end{tabular}

Sources and notes: Data include both retail and wholesale margins and costs. Each quartile comprises 22 stores (apart from the highest quartile, which has 21). * Estimated from store payroll expenses using an average payroll per person figure derived from wages and salaries for Boots' retail section (from the Boots detailed accounts for the year ending $31^{\text {st }}$ March 1938), divided by the number of branch store workers given in the Statistical Digest for the same year. 
Table 6. Pairwise correlations between net margins and sales across size categories

\begin{tabular}{lcc}
\hline \multicolumn{1}{c}{ Size $(£, 000 \mathrm{~s})$} & $1920 \mathrm{~s}$ & $1930 \mathrm{~s}$ \\
\hline$<5$ & $0.5026 *$ & $0.2247^{*}$ \\
$5-10$ & 0.0705 & $0.3599 *$ \\
$10-20$ & $-0.2829 *$ & -0.0454 \\
$>20$ & $-0.3036^{*}$ & -0.0789 \\
\hline
\end{tabular}

Note: $* \mathrm{p}>0.01$. None of the other correlations are significant even at the $10 \%$ level. 
Figure 1. Distribution of the Boots sample stores by size categories (1923-1938)

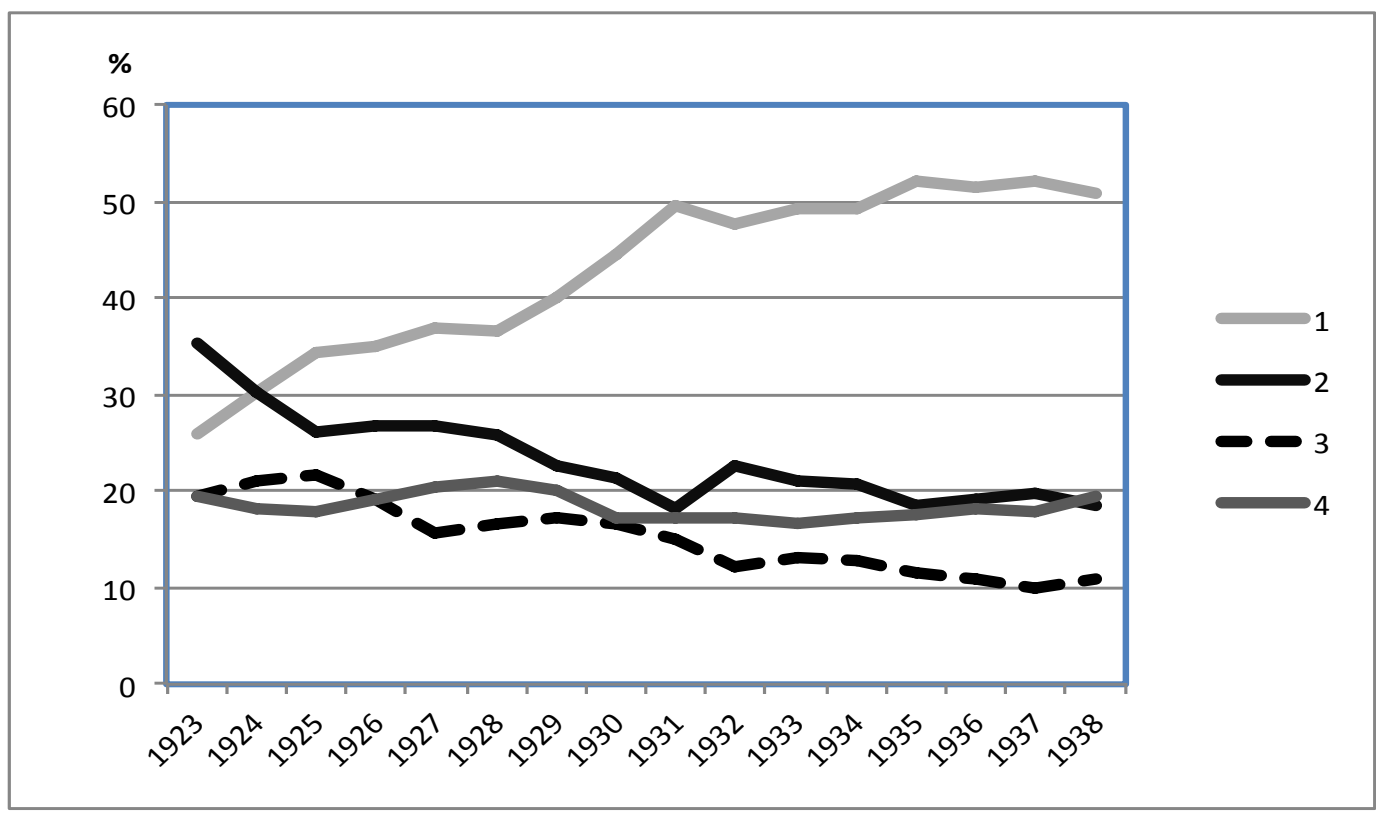

Sources: see text. 
Figure 2: Relationship between Net Margin and Store Size for three bench mark years $(1924,1929,1938)$
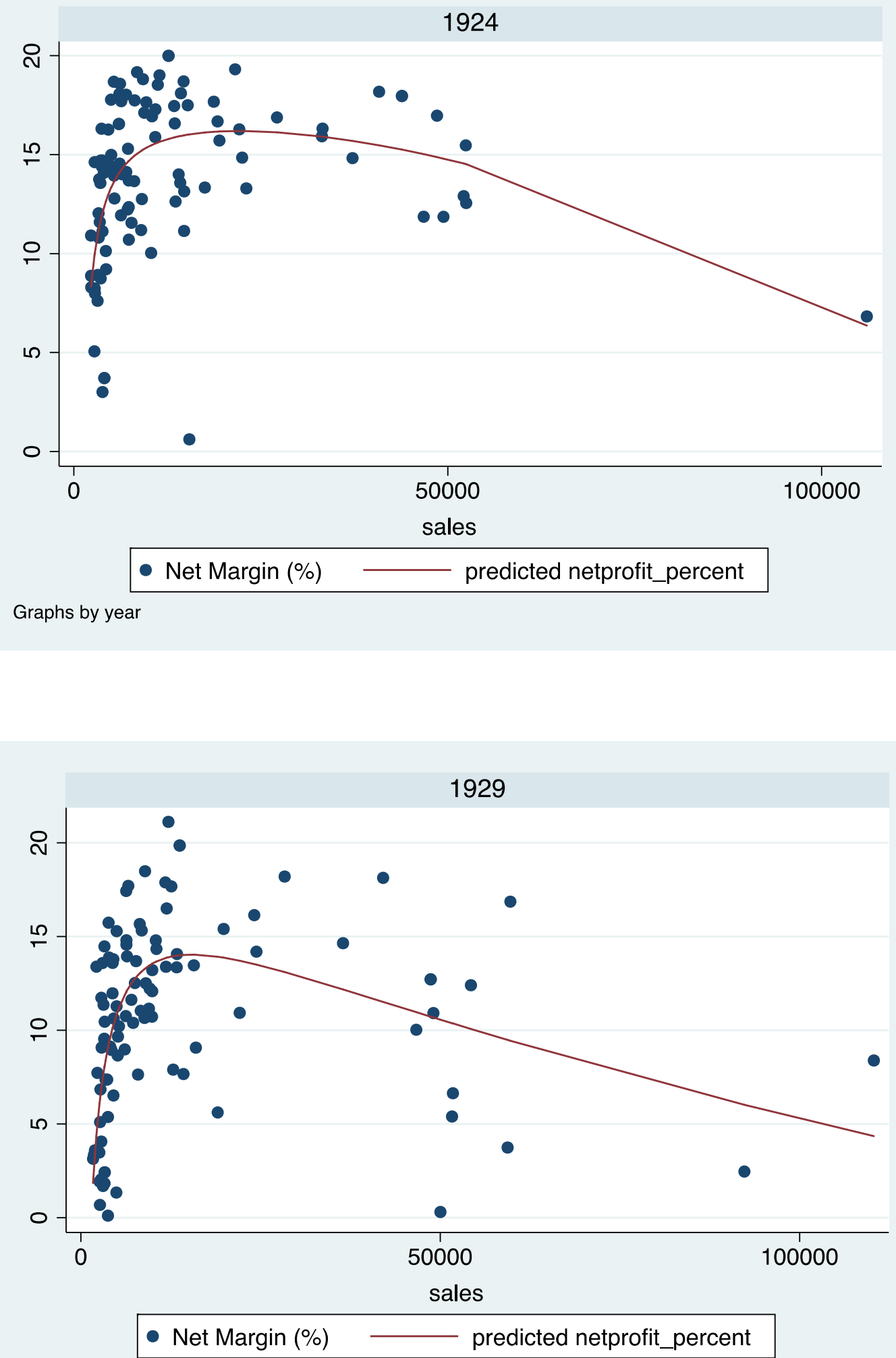

Graphs by year 


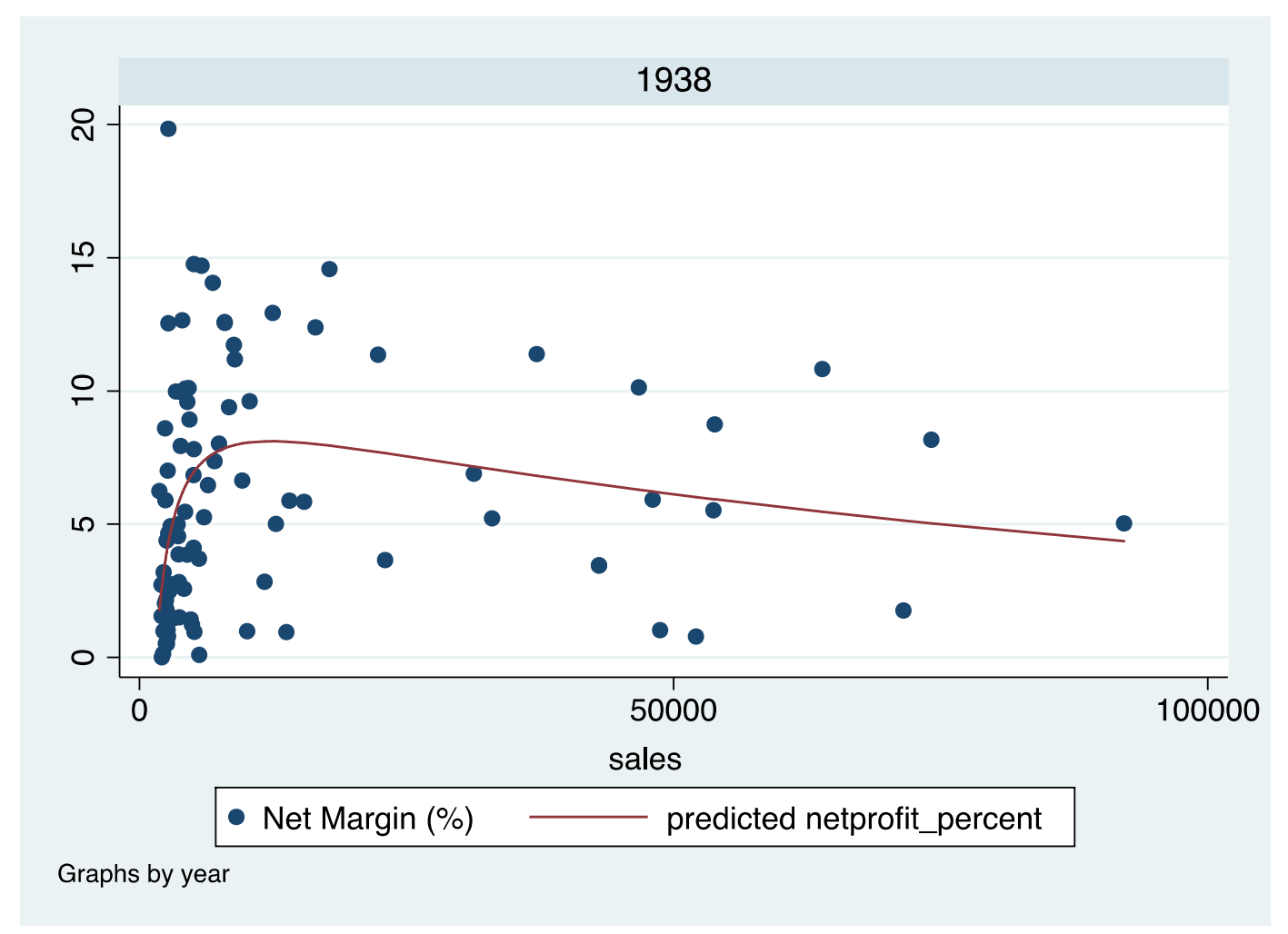

Sources: see text.

\footnotetext{
${ }^{\mathrm{i}}$ Chandler, Scale and Scope, 259; 261.

ii Broadberry, Market Services, 245-252; 279.

iii Jefferys, Retail Trading, 69-70; 80-83; 88-91.

iv Broadberry, Market Services, 67; 245-46.
}

${ }^{v}$ Royal Pharmaceutical Society Library Archives [hereafter RPS], IRA 1996.417, "Survey of Retail Organisation and Trends," O.W. Roskill, 5 July 1939.

vi Rowntree, Poverty and progress, 59-60; Borthwick Institute, York, B. S. Rowntree papers, Poverty \& Progress Survey, PP42, letter, F.D. Stuart to J. M. Richards, 30 March 1942, showing data from 1936 York shops survey. For a summary of official investigations see Phillips and Alexander, "Efficient Pursuit?" vii Scott, and Walker, "Barriers to Industrialisation"; idem, "British 'Failure"".

viii UK, Board of Trade, Report of the Committee on Resale Price Maintenance, 1.

ix Winstanley, "Concentration and competition," 252-3.

${ }^{x}$ Jefferys, Distribution, 377-399.

${ }^{x i}$ Ibid, 391.

xii See Curtis, "Resale Price Maintenance," 353.

xiii Jefferys, Retail Trading, 379.

xiv Slinn, "Boots Company plc".

${ }^{x v}$ Brownfield-Pope, "Chemist shop to Community Pharmacy", 28-30.

xvi Ibid, 48.

xvii Jefferys, Retail Trading, 382.

xviii Ibid, 385.

xix Chapman, "Boot, Jesse."

${ }^{x x}$ Chapman, Jesse Boot, 41.

xxi Boots advertisement, Manchester Guardian (15 December 1904), 4.

xxii Chapman, "Boot, Jesse;" Greenwood, Cap for Boots, 15. 
xxiii Boots plc Archives, Nottingham [hereafter Boots Archives], Boots advert, Daily Mail, 25 March 1910.

xxiv Chapman, Jesse Boot, 88.

${ }^{\mathrm{xxv}}$ Slinn, "Boots Company plc," 18.

xxvi Chapman, Jesse Boot, 78; 91.

xxvii Brownfield-Pope, "Chemist Shop to Community Pharmacy," 70.

xxviii RPS, IRA 1996.432, Pharmaceutical Society of Great Britain [hereafter Pharmaceutical Society], Report of the Committee of Enquiry (Part I), 16.

xxix Holloway, Royal Pharmaceutical Society, 317.

xxx Levy, Retail Trade Associations, 86.

xxxi Brownfield-Pope, "From chemist shop to community pharmacy," 55; Holloway, Royal Pharmaceutical Society, 318-320.

xxxii Holloway, Royal Pharmaceutical Society, 317.

xxxiii UK, Board of Trade, Report of the Committee on Resale Price Maintenance, 44.

xxxiv Jefferys, Retail Trading, 73; 396.

xxxv Ibid, 387.

xxxvi Boots Archives, Boots Ltd, Statistical Record for year to $31^{\text {st }}$ March 1939; 2961/6, Report by A. J. Espley, Managing Director, Timothy Whites \& Taylors Ltd, for Pharmaceutical Society, 24 March 1939.

xxxvii Jefferys, Retail Trading, 73 \& 396.

xxxviii Morelli, "Constructing a balance," 48.

xxxix See Curtis, "Resale Price Maintenance," 352.

${ }^{\mathrm{xl}}$ Morelli, "Information costs; idem, "Constructing a balance," 48.

xli Mercer, "Retailer-supplier Relationships," 140-141.

xlii Burt and Sparks, "Power and competition," 243-8; see also Morelli, "Constructing a balance," 47-49; Curtis,

"Resale Price Maintenance," 352-3.

xliii Grant, "Manufacturer-retailer relations," 53.

xliv For a discussion of the retail hierarchy model, see, Shaw, Alexander, Benson, and Jones, "Structural Trends."

xlv Boots Archives, A89/33, document setting out the duties of territorial general managers, n.d., c. 1934-38;

“Accounts and Why?" The Bee, March 1922, 13-14. Chapman, Jesse Boot, 151; Greenwood, Cap for Boots, 2124.

xlvi Chapman, Jesse Boot, 148-50.

xlvii Boots Archives, 2961/6, Report by A. J. Espley, Managing Director, Timothy Whites \& Taylors Ltd, for Royal Pharmaceutical Society, 24 March 1939; "Taylors (Cash Chemists) London Limited." Times [London, England] 12 Nov. 1928: 26. The Times Digital Archive. Web. 24 Feb. 2017; Sneader, "Growth of multiple pharmacy," 13.

xlviii Boots Archives, 2961/6, Report by A. J. Espley, Managing Director, Timothy Whites \& Taylors Ltd, for

Royal Pharmaceutical Society, 24 March 1939.

xlix Ibid.

${ }^{1}$ Ibid; Boots Archives, Y115, Timothy White \& Taylors Ltd, share prospectus, $29^{\text {th }}$ April 1935.

${ }^{\text {li }}$ Boots Archives, Y115, Timothy White \& Taylors Ltd Directors Report and Accounts for $27^{\text {th }}$ September 1936 to $1^{\text {st }}$ January 1938.

lii Boots Archives, Y115, copy of Philip Hill's speech, at 29 April 1938 AGM, from the Times, 30 April 1938; Boots Statistical Record for year to $31^{\text {st }}$ March 1938.

liii Jefferys, Distribution, 389-92.

liv RPS, IRA 1996.432, Pharmaceutical Society, "Report of the Committee of Enquiry, Part I," (May 1939), 10.

lv Kipping, "Research department,"303-4; Boots Archives, A. E. Davis, "Research and development at Boots," unpublished history of Boots research activities, November 1981, 3-8.

lvi Boots Archives, Statistical Report, year ending $31^{\text {st }}$ March 1938 and Expenses report, year ending $31^{\text {st }}$ March 1932.

lvii Boots Archives, reports on Boots associated companies accounts for year ended 31 ${ }^{\text {st }}$ March 1938, 13; ibid, report for year ended 31 $1^{\text {st }}$ March 1937, 10. See also Jefferys, Distribution, 391-2.

lviii Boots Archives, Y115, Timothy White and Taylor, "Your own Company Provides Everything for Health \&

Home," internal brochure, autumn 1937.

lix Corley, Beechams, 116-17. For credence goods, see Darby and Karni, "Free Competition."

${ }^{1 x}$ Boots plc Archives, advertising file, copies of adverts in Glasgow Bulletin, 31 Jan. 1930; Radio Times, 11 Sept. 1931. Emphasis in originals.

lxi Boots plc Archives, advertising file, copy of advert in Radio Times, $25^{\text {th }}$ April 1932. Emphasis in original.

lxii That solving medical and other information asymmetries relating to customers' purchasing needs by staff can bestow benefits on both firms and consumers is highlighted in Godley, and Casson, "'Doctor, Doctor..."' 
1xiii For private brands enhancing customer loyalty, see Koschate-Fischer, Cramer, and Hoyer, "Moderating Effects;" Ailawadi, and Keller, "Understanding Retail Branding;" Ailawadi, Koen, and Steenkamp, "Private-label Use."

lxiv Boots Archives, "History of No. 7," case-study folder, prepared by the archives staff.

lxv Jefferys, Retail Trading, 391-2.

lxvi Phillips, "Chemists to the Nation," 246.

Ixvii Boots Archives, Statistical Record, 1939.

lxviii Boots Archives, Library Department reports for years ending $31^{\text {st }}$ March 1938 and 1939.

lxix Woolworths virtual museum, htt://museum.woolworths.co.uk/1932advert.htm, accessed 25 March 2008.

lxx Chapman, "Boot, John Campbell."

Ixxi See Akehurst, "Concentration”, 30.

lxxii Burt and Sparks, 'Power and Competition,” 249.

lxxiii Chapman, Jesse Boot, 153.

lxxiv Boots Archives, Statistical Report, 1938; Expenses Report, 1930.

1xxv Boots Archives, Y115, Timothy White \& Taylors Ltd Directors Report and Accounts for $27^{\text {th }}$ September 1936 to $1^{\text {st }}$ January 1938.

lxxvi Boots Archives, Y115, Timothy White \& Taylors Ltd annual reports and accounts, 1929-1939; Boots Ltd, Statistical reports, 1926-1939.

lxxvii Jefferys, Retail Trading, 395. This trend is supported by Kellys directory data analysed by Brownfield-

Pope, "Chemist Shop to Community Pharmacy," 46-48.

lxxviii RPS, IRA 1996.432, Pharmaceutical Society, "Report of the Committee of Enquiry, Part I (May 1939)," 16.

lxxix Ibid, 10.

lxxx RPS, IRA 1996.417, "Survey of Retail Organisation and Trends,” 0.W. Roskill, 5 July 1939, 305.

lxxxi RPS, IRA 1996.432, Pharmaceutical Society, "Report of the Committee of Enquiry, Part I (May 1939$), " 10$.

lxxxii Ibid, 12; Boots plc, 2961/6, Report by A. J. Espley, Managing Director, Timothy Whites \& Taylors Ltd, for Pharmaceutical Society, 24 March 1939.

Ixxxiii RPS, IRA 1996.432, Pharmaceutical Society, "Report of the Committee of Enquiry, Part I” (May 1939), 12.

lxxxiv Boots plc, 2961/6, Report by A. J. Espley, Managing Director, Timothy Whites \& Taylors Ltd, for

Pharmaceutical Society, 24 March 1939; RPS, IRA 1996.432, Pharmaceutical Society, "Report of the

Committee of Enquiry, Part I" (May 1939), 10.

lxxxv RPS, IRA 1996.417, 'Survey of retail organisation and trends, 0.W. Roskill, 5 July 1939, 304.

${ }^{\text {lxxxvi }}$ RPS, IRA 1996.432, Pharmaceutical Society, "Report of the Committee of Enquiry, Part I" (May 1939), p.

12 \& Appendix 13.

Ixxxvii Pharmaceutical Society of Great Britain, Report of the Committee of Enquiry (Part 2), pp. 4-5. For

voluntary chains see Morelli, "Constructing a balance," 50-51.

Ixxxviii Brownfield-Pope, "From chemist shop to community pharmacy," 108.

1xxxix RPS, IRA 1996.432, Pharmaceutical Society, "Report of the Committee of Enquiry, Part I" (May 1939),

17.

xc RPS, IRA 1996.432, Pharmaceutical Society of Great Britain, Report of the Committee of Enquiry (Part 2), 56.

${ }^{\text {xci }}$ RPS, IRA 1996.352. Minutes of Committee of Enquiry,19 $19^{\text {th }}$ Oct. 1937.

xcii Ibid, $28^{\text {th }}$ September 1938 and $24^{\text {th }}$ May 1939.

xciii RPS, IRA 1996.432, Pharmaceutical Society, "Report of the Committee of Enquiry, Part I” (May 1939 ), 14.

xciv Ibid, 12.

${ }^{\mathrm{xcv}}$ Ibid, Appendices 3-4.

xcvi Ibid, 15.

xcvii Boots Archives, 461/1, Boots Ltd, "Statistical Record", 1926-39; Box 1167, detailed accounts and notes to the accounts, 1930-39; Box 820, store performance cards for those stores open from 1923 to1938.

xcviii RPS, IRA 1996.432, Pharmaceutical Society, "Report of the Committee of Enquiry, Part I (May 1939$), " 10$.

xcix Boots Archives, Boots Ltd, Statistical Record for year to 31 ${ }^{\text {st }}$ March 1939; 2961/6, Report by A. J. Espley,

Managing Director, Timothy Whites \& Taylors Ltd, for Pharmaceutical Society, 24 March 1939.

${ }^{\mathrm{c}}$ Commissions and bonuses taken from Boots Archives, Statistical Report for year to $31^{\text {st }}$ March 1939, payroll comparison, data for year to $31^{\text {st }}$ March 1938.

${ }^{\text {ci }}$ Data for 20 smallest and largest stores are from Boots Archives, Statistical Report for year to $31^{\text {st }}$ March 1938.

cii We also experimented with removing one particularly large store that had a disproportionate impact on average turnover for the top quartile, but its omission had no substantial impact on any of the other ratios. 
ciii This assumes that the 'wages and salaries' heading in the detailed accounts is identical to the payroll expenses heading in the store-level accounts and that all retail section staff were based in the branches (other than territorial general managers and stock-takers, whose salaries were listed separately).

civ Boots Archives, report on accounts for year to $31^{\text {st }}$ March 1937. The report also noted the adverse impact of population decentralisation.

${ }^{\text {cv }}$ RPS, IRA 1996.417, 0.W. Roskill, 'Survey of retail organisation and trends,' unpublished report, 5 July 1939.

cvi See Scott and Walker, "Barriers to Industrialisation", 188-196; idem, "British Failure", 282-295; idem, "Large-scale Retailing," 114-116.

cvii See Mills, "Why Retailers Sell Private Labels," for some empirical evidence and rationale.

cviii Brownfield-Pope, "From chemist shop to community pharmacy," 86 \& 104; Pharmaceutical Society of Great Britain, Report of the Committee of Enquiry (Part 2), 7.

${ }^{\text {cix }}$ US fair trade legislation was mainly introduced at state level. 